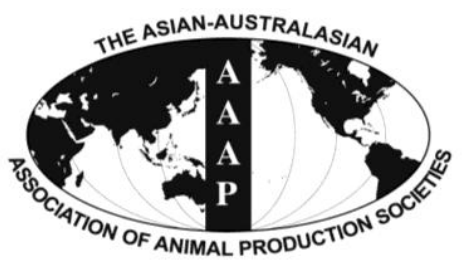

Asian-Aust. J. Anim. Sci.

Vol. 25, No. 12 : 1691-1700 December 2012

http://dx.doi.org/10.5713/ajas.2012.12052

www.ajas.info

pISSN 1011-2367 elSSN 1976-5517

\title{
Effect of Harvesting Frequency, Variety and Leaf Maturity on Nutrient Composition, Hydrogen Cyanide Content and Cassava Foliage Yield
}

\author{
Khuc Thi Hue, Do Thi Thanh Van ${ }^{1}$, Inger Ledin ${ }^{2}$, Ewa Wredle ${ }^{2}$ and Eva Spörndly ${ }^{2, *}$ \\ Goat and Rabbit Research Center, Sontay, (84-043) Hanoi, Vietnam
}

\begin{abstract}
The experiment studied the effect of harvesting frequencies and varieties on yield, chemical composition and hydrogen cyanide content in cassava foliage. Foliage from three cassava varieties, K94 (very bitter), K98-7 (medium bitter) and a local (sweet), were harvested in three different cutting cycles, at 3,6 and 9 months; 6 and 9 months and 9 months after planting, in a 2-yr experiment carried out in Hanoi, Vietnam. Increasing the harvesting frequency increased dry matter (DM) and crude protein (CP) production in cassava foliage. The K94 variety produced higher foliage yields than the other two varieties. Dry matter, neutral detergent fibre (NDF), acid detergent fibre (ADF) and total tannin content increased with months to the first harvest, whereas CP content decreased. Hydrogen cyanide $(\mathrm{HCN})$ content was lower at the first harvest than at later harvests for all cutting cycles. At subsequent harvests the content of total tannins tended to decline, while HCN content increased $(\mathrm{p}<0.05)$. Chemical composition differed somewhat across varieties except for total tannins and ash. Dry matter, NDF, ADF and total tannins were higher in fully matured leaves, while CP and HCN were lower in developing leaves. (Key Words: Manihot esculenta Crantz, Cassava Foliage, Harvesting Frequency, Variety, Yield, HCN)
\end{abstract}

\section{INTRODUCTION}

Cassava (Manihot esculenta Crantz) has previously been cultivated mainly for the roots and in many countries, such as Vietnam, the foliage has only been used for animal feed in small amounts at root harvesting time. Nowadays, farmers are using cassava as a dual-purpose plant for both root and foliage production, harvesting smaller stems frequently during the 9 month growing period. The foliage contains approximately $21 \%$ crude protein (CP) with a range from 17 to $40 \% \mathrm{CP}$ depending on cultivar, maturity, sampling procedure, soil fertility and climate (Ravindran, 1993). According to Ravindran (1993), the amount of foliage available at root harvesting is equivalent to about $30 \%$ of the root yield and comprises about 5 tons of dry matter (DM) (Erdmann et al., 1993) per hectare.

It is an already known fact that increased foliage harvest

\footnotetext{
* Corresponding Author: Eva Spörndly. Tel: +46-(0)18671632, Fax: +46-(0)8672946, E-mail: Eva.Sporndly@slu.se

${ }^{1}$ National Institute of Animal Sciences, Hanoi, Vietnam.

2 Department of Animal Nutrition and Management, Swedish University of Agricultural Sciences, P.O. Box 7024, SE-75007 Uppsala, Sweden.

Submitted Jan. 31, 2012; Accepted May 2, 2012; Revised Jul. 1, 2012
}

frequency resulted in reduced root production at around 10 months after planting (Khang et al., 2005; Phengvichith et al., 2006). However, cassava planted for foliage produced a greater amount of leaf biomass through more frequent harvests. The accumulated KM 94 cassava harvested at harvesting intervals of 45, 60, $90 \mathrm{~d}$ produced more foliage compared with a single harvest at $285 \mathrm{~d}$ (Khang et al., 2005). There was a positive correlation between foliage production and cutting frequency (Wanapat, 2003).

Using fresh cassava foliage as a feed for ruminants can be a problem due to its fairly high content of hydrogen cyanide (HCN) (Hue et al., 2010). According to Ravindran (1993), the normal range of HCN content in cassava foliage is 200 to $800 \mathrm{mg} / \mathrm{kg}$ of fresh leaves, with the variation being attributed to genetic, physiological and edaphic factors, and climate. One of the more important differences between different varieties of cassava is in the content of HCN. In many cases the varieties with high $\mathrm{HCN}$ content are referred to as very bitter or bitter varieties while those low in $\mathrm{HCN}$ are classified as sweet varieties (Mlingi et al., 1995). In a study from Nigeria, where 17 different varieties were compared, there was a 10 -fold difference between the variety with $122 \mathrm{ppm}$ and 1,040 ppm $\mathrm{HCN}$ in fresh leaves for the variety with the highest and lowest HCN content, 
respectively (Ubi et al., 2008). They also found that the total HCN content of the roots were not correlated with the content in the leaves of the same plant. Therefore the classifications of "bitter" and "sweet" may not be applicable when regarding the whole plant. Twenty varieties were compared in a study performed in Vietnam where there was a three-fold difference between the HCN content in cassava foliage of the variety with the lowest and highest $\mathrm{HCN}$ content (range 610 to $1,840 \mathrm{mg} / \mathrm{kg} \mathrm{DM}$ ) at root harvest (Hang and Preston, 2005). HCN content in leaves was higher than in petioles or stems and the content in leaves varied less in soils than in varieties (Arvidsson and Sandberg, 2003). In an earlier study HCN content in the cassava foliage differed in varieties but ranged from 1,500 to 2,000 mg/kg DM (Gômez and Valdivieso, 1985). There were considerable differences in chemical composition of the foliage from different varieties harvested at different harvest occasions, showing some interaction between variety and harvest management.

Another important aspect of cassava foliage is the content of condensed tannins. Khang et al. (2005) reported that unlike $\mathrm{HCN}$, the content of condensed tannins in foliage increased at longer harvest intervals, ranging from approximately $3.5 \%$ of $\mathrm{DM}$ at $45 \mathrm{~d}$ harvest interval to around $4.3 \%$ of DM at root harvest stage. Significant tannin differences in varieties was also reported by Oni et al. (2011). The impact of condensed tannins in cassava forage on protein digestibility was studied by Reed et al. (1982) but information addressing cassava harvested for forage is still limited.

The objectives of the present study were to evaluate productivity of cassava and to determine the chemical composition in foliage, especially the tannin and $\mathrm{HCN}$ content, in several different varieties harvested at three harvest frequencies. Furthermore, the objective was also to compare the chemical composition of young and old leaves within the sward in a system with only one single harvest at 9 months.

\section{MATERIALS AND METHODS}

\section{Location and climate}

The experiment was carried out in the field of The Goat and Rabbit Research Centre, Sontay, Hanoi, Vietnam (longitude $105^{\circ} 25 \mathrm{E}$; latitude $21^{\circ} 06 \mathrm{~N}$ altitude $220 \mathrm{~m}$ above sea level. The climatic conditions at the present study area was typical tropical monsoon (Figure 1) as reported by Bavi Meteor Centre, which is situated $1 \mathrm{~km}$ from the experimental area with the same climatic conditions. The rainy season lasts from April to October with a peak in rainfall in July and August. The dry season is from November to March. Average annual rainfall in the two experimental years (2009 and 2010) was 1,240 mm, while monthly mean temperature ranged from 14.7 to $29.9^{\circ} \mathrm{C}$, with a minimum in January and a maximum in June. The experiment lasted from early March to November in both years.

\section{Establishment of cassava plot}

The experimental design of the study was a two factorial design studying varieties and harvesting frequencies. Three cassava varieties (K94; K98-7; and a local variety) were compared and three harvest frequencies (three cuttings at 3, 6 and 9 months; two cuttings at 6 and 9 months; and a single harvest at root harvesting). There were four replications of each combination of variety and harvesting frequency.

The K94 cassava variety was originally imported from Thailand around 1990 with the original name of KU50 (or Kasetsart 50) and it has a growing period of 9 to 11 months. The characteristics of this variety are green stems without divided branches, large leaf blades and green petioles, but

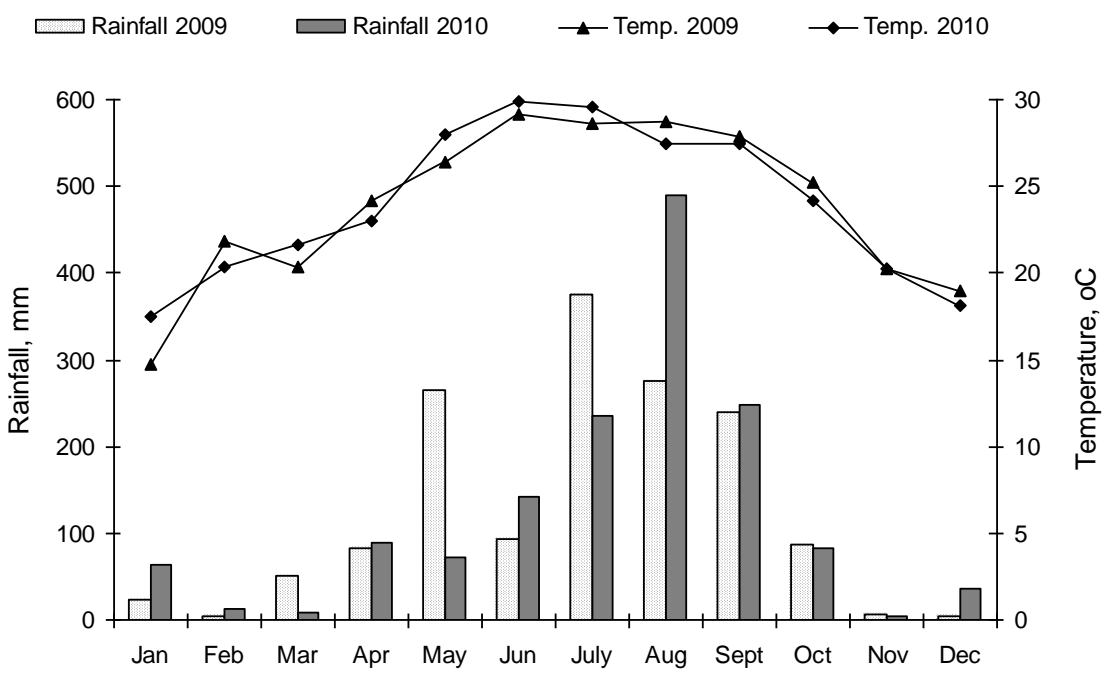

Figure 1. Average environmental temperature and rainfall in Bavi in 2009 and 2010. 
there is red coloration on the tops of the foliage. The cassava variety K98-7 was originally introduced from Colombia as a crossbreed between SM1717 and CM322188 , and has brown stems without divided branches, narrow leaf blades and red petioles and a growing period of 7 to 10 months after planting. The local cassava variety has hard green stems, large and short leaf blades and green petioles. The three cassava varieties K94, K98-7 and local were defined according to their taste as very bitter, medium bitter and sweet, respectively.

The experiment was conducted in a $2,300 \mathrm{~m}^{2}$ field, $1,800 \mathrm{~m}^{2}$ of which was used for planting and $500 \mathrm{~m}^{2}$ consisted of borders around the whole planting area. Each plot consisted of $50 \mathrm{~m}^{2}(5 \mathrm{~m} \times 10 \mathrm{~m})$.

Stem cuttings of cassava were taken from stems that were healthy and free from diseases. The stems were taken around the centre and were cut into segments of 20 to $25 \mathrm{~cm}$ in length just before planting. The stems were planted at 15 to $20 \mathrm{~cm}$ depth in continuous rows, with $60 \mathrm{~cm}$ between rows and $40 \mathrm{~cm}$ between plants. In each plot, a hundred cassava stems were planted and total 3,600 stems were used in each year of the experiment.

The soil at the experimental site is Feralite Acrisol type, acidic and with low fertility. The soil had the following chemical characteristics: $\mathrm{H}_{\mathrm{KCl}} 4.12$, organic matter $(\mathrm{OM})$ $4.48 \%, \mathrm{~N}_{\text {total }} 1.6 \mathrm{mg} / \mathrm{kg}, \mathrm{K}_{2} \mathrm{O}_{\text {total }} 4.6 \mathrm{mg} / \mathrm{kg}$ and $\mathrm{P}_{2} \mathrm{O}_{5} 0.39$ $\mathrm{mg} / \mathrm{kg}$ (Dung et al., 2005). Previously, the area has been used for cassava cultivation. Before planting, the experimental land was first cleared of weeds and then ploughed by tractor-drawn mouldboard plough to a depth of 20 to $25 \mathrm{~cm}$ to loosen the soil before slashing and dividing into plots. Weeds were also removed once again before planting. Each experimental year, the entire experimental area used for cassava cultivation was fertilised with goat manure corresponding to 200 tons/ha, $500 \mathrm{~kg}$ NPK (8:10:14)/ha and $300 \mathrm{~kg}$ urea/ha. All manure and half the NPK and urea were applied at planting, while the remaining NPK and urea were divided equally and applied at 3 and 6 months after planting for all treatments. Weed control was performed once a month. In all treatments, watering was carried out on day one and d 15 of every month except when natural precipitation occurred on these days.

On the first harvesting occasion, the foliage shoots from the planted cassava stems were manually harvested by breaking them at 10 to $15 \mathrm{~cm}$ above the ground. On subsequent harvesting occasions, the foliage was broken at 10 to $15 \mathrm{~cm}$ above the starting point of new branches emerging from the old cassava stems. The foliage was harvested at 7:00 to 9:00 am to avoid fluctuations in $\mathrm{HCN}$ content, which tend to occur later during the day owing to the wide variation in temperature due to solar radiation (Stochmal and Oleszek, 1997).

Cassava foliage was considered to be all the aboveground biomass (including thin stems, twigs and leaves) that animals could consume, i.e. which still had green leaves left. Old cassava stems without any remaining green leaves were not included.

\section{Data and sample collection}

Foliage biomass yield of the three different cassava varieties was measured at each harvesting occasion. The fresh foliage was weighed immediately after harvesting and, based on the harvested amounts and the chemical composition, the total DM and CP yields were calculated.

At each harvest, four samples of foliage were taken separately from each cassava variety for analysis of the chemical composition and $\mathrm{HCN}$ content. Each sample (approx. $1 \mathrm{~kg}$ fresh weight) was collected randomly from 5 to 6 cassava plants at harvesting.

Additional sampling was performed in the single harvest system to study the difference in chemical composition in newly emerged leaves and older leaves within the same crop in a system with one single harvest at 9 months. The samples used for analysing the chemical composition and $\mathrm{HCN}$ content at different stages of maturity (young and old leaves) were taken after 9 months of uninterrupted growth (1-Harvest) in both years. Samples were taken with four replicates per cassava variety and year. The young stage of maturity was classified as the four youngest leaves from the top of the foliage, while the old stage of maturity consisted of the four oldest green leaves from the foliage at the bottom of the stems.

All foliage samples were chopped into 1 to $2 \mathrm{~cm}$ lengths and preserved within a day before being sent to the laboratory. The samples for determining DM, CP, ash, neutral detergent fibre (NDF), acid detergent fibre (ADF) and total tannins were stored at $4^{\circ} \mathrm{C}$. The samples for analysing the $\mathrm{HCN}$ content were stored at $-30^{\circ} \mathrm{C}$ until analysis to avoid variations in the $\mathrm{HCN}$ content due to temperature. Dry matter, total tannins and $\mathrm{HCN}$ content were analysed according standard methods of AOAC (1990). Nitrogen $(\mathrm{N})$ was determined by the Kjeldahl procedure (AOAC, 1990). Neutral detergent fibre and ADF were determined by the methods of van Soest et al. (1991).

\section{Statistical analysis}

The data were analysed using the GLM procedure of SAS software (SAS, 2008). Treatment means which showed significant differences at the probability level of $\mathrm{p}<0.05$ were compared using Tukey's pair-wise comparison procedures. There was a lack of significance for the variable year and its interactions with treatments and varieties. The lack of significance of year and its interactions was applicable for all the response variables (yield and chemical components). Therefore year and its interactions were excluded from the model and the final statistical model for 
Table 1. Dry matter and crude protein yield of three varieties of cassava foliage with a three-, two- or one harvest system at 3,6 or 9 months after planting (tons/ha)

\begin{tabular}{|c|c|c|c|c|c|c|c|c|c|c|c|}
\hline \multirow{3}{*}{ Component } & \multirow{3}{*}{ Variety $^{1}$} & \multicolumn{8}{|c|}{ Month after planting } & \multirow{3}{*}{ SEM $_{\text {Harvest }}$} & \multirow{3}{*}{$\mathrm{SEM}_{\text {Total }}$} \\
\hline & & \multirow{2}{*}{$\frac{\text { 1-Harvest }}{\text { Month } 9}$} & \multicolumn{3}{|c|}{ 2-Harvests } & \multicolumn{4}{|c|}{ 3-Harvests } & & \\
\hline & & & Month 6 & Month 9 & Total & Month 3 & Month 6 & Month 9 & Total & & \\
\hline \multicolumn{12}{|c|}{ Dry matter yield (ton/ha) } \\
\hline & K94 & $5.3^{\mathrm{cX}}$ & 4.5 & 1.6 & $6.1^{\mathrm{bX}}$ & 2.0 & 2.8 & 1.6 & $6.3^{\mathrm{aX}}$ & & \\
\hline & K98-7 & $4.5^{\mathrm{cZ}}$ & 4.0 & 1.4 & $5.4^{\mathrm{bZ}}$ & 1.7 & 2.5 & 1.4 & $5.6^{\mathrm{aZ}}$ & & \\
\hline & Local & $4.8^{\mathrm{cY}}$ & 4.1 & 1.6 & $5.7^{\mathrm{bY}}$ & 1.7 & 2.5 & 1.6 & $5.8^{\mathrm{aY}}$ & 0.16 & 0.05 \\
\hline \multicolumn{12}{|c|}{ Crude protein yield (ton/ha) } \\
\hline & K94 & $1.00^{\mathrm{cX}}$ & 0.85 & 0.32 & $1.17^{\mathrm{bX}}$ & 0.44 & 0.55 & 0.31 & $1.30^{\mathrm{aX}}$ & & \\
\hline & K98-7 & $0.80^{\mathrm{cZ}}$ & 0.75 & 0.28 & $1.02^{\mathrm{bZ}}$ & 0.39 & 0.46 & 0.27 & $1.11^{\mathrm{aZ}}$ & & \\
\hline & Local & $0.89^{\mathrm{cY}}$ & 0.76 & 0.31 & $1.07^{\mathrm{bY}}$ & 0.34 & 0.55 & 0.36 & $1.26^{\mathrm{aY}}$ & 0.04 & 0.009 \\
\hline
\end{tabular}

${ }^{1}$ Cassava varieties: K94, K98-7 and local = very bitter, medium bitter and sweet taste, respectively.

a,b,c Numbers followed by the same letters were not significantly different $(\mathrm{p}<0.05)$ within a row.

$\mathrm{X}, \mathrm{YZZ}$ Numbers followed by the same letters were not significantly different $(\mathrm{p}<0.05)$ within column.

Least square means and standard error of means (SEM).

analysing the yield of biomass, DM, CP, chemical composition and $\mathrm{HCN}$ content was: $\mathrm{Y}_{\mathrm{ijk}}=\mu+\mathrm{H}_{\mathrm{i}}+\mathrm{V}_{\mathrm{j}}+\mathrm{HV}_{\mathrm{ij}}$ $+\mathrm{e}_{\mathrm{ijk}}$, where $\mathrm{Y}_{\mathrm{ijk}}$ is the dependent variable, $\mu$ is the overall mean, $\mathrm{H}_{\mathrm{i}}$ is the effect of harvesting interval, $\mathrm{V}_{\mathrm{j}}$ is the variety effect, $\mathrm{HV}_{\mathrm{ij}}$ is the interaction between harvesting intervals and variety and $\mathrm{e}_{\mathrm{ijk}}$ is the random error, independent and normally distributed.

The statistical model for analysing the chemical composition and $\mathrm{HCN}$ content of cassava foliage at different stages of maturity was: $\mathrm{Y}_{\mathrm{ijk}}=\mu+\mathrm{V}_{\mathrm{i}}+\mathrm{M}_{\mathrm{j}}+\mathrm{VM}_{\mathrm{ij}}+\mathrm{e}_{\mathrm{ijk}}$, where $Y_{i j k}$ is the dependent variable, $\mu$ is the overall mean, $V_{i}$ is the effect of variety, $M_{j}$ is effect of stage of maturity, $\mathrm{VM}_{\mathrm{ij}}$ is the interaction between variety and stage of maturity and $e_{i j k}$ is the random error, independent and normally distributed.

\section{RESULTS}

\section{Effect of harvesting interval and variety on yield and content of nutrients}

Table 1 shows that there was a positive correlation between harvesting frequency and total yield of DM and CP, with all these being highest in the treatment of harvests every three months after planting. Lower yields were lower with two harvests and yet lower with only a single harvest 9 months after planting. Significant differences in total DM and $\mathrm{CP}$ production were also obtained between the varieties at all harvesting frequencies (Table 1).

Harvesting interval affected the chemical composition of the cassava foliage (Table 2) and significantly higher DM content was obtained at the 9 month cut in both the three harvest and two harvest treatments while the highest DM content was found in the single harvest treatment. The DM content was significantly higher in the local variety, while the K98-7 and K94 varieties did not differ significantly.
The CP content of the foliage did not differ in variety, but differed by harvest interval. Numerically highest CP content in foliage was obtained at the 3 month cut under the three harvest frequency treatment and the lowest CP content was obtained at the 9 month cut under the single harvest. In contrast to the pattern of $\mathrm{CP}$ content, the NDF and ADF fraction in the foliage were higher at the later harvests. The highest NDF content was obtained at the 9 month cut in the single harvest treatment. Among the cassava varieties, the NDF and ADF fractions were generally higher in the local variety than in the K94 and K98-7 varieties. No significant differences were found in ash content which ranged from 5.5 to $5.8 \%$ of DM.

\section{Effect of harvesting interval, variety and leaf maturity on total tannin and HCN content}

The content of total tannins (Table 3) did not differ between cassava varieties, but was significantly affected by the harvest interval. Total tannin content in cassava foliage was significantly higher at the first harvests after planting in the multiple harvest systems, and decreased in the following foliage harvest. Among the harvesting times, the content of total tannins was highest at 9 months after planting in the single harvest treatment. The HCN content in foliage was affected by both harvesting interval and variety. The highest $\mathrm{HCN}$ content was obtained in the harvests at 6 , and 9 months in the three harvest system and the harvest at 9 months in two the harvest system. The HCN content decreased significantly when the first harvest was delayed. Among the cassava varieties, the highest HCN content in foliage was found in the K94 variety and the lowest in the local variety.

Comparing the chemical composition of cassava leaves at different stages of maturity (young and old) within the one harvest system shows that the content of total tannins in 
Table 2. Dry matter and nutrient content of three varieties of cassava foliage with a three, two or one harvest system at 3,6 , and 9 months after planting

\begin{tabular}{|c|c|c|c|c|c|c|c|c|}
\hline \multirow{3}{*}{ Content } & \multirow{3}{*}{ Variety $^{1}$} & \multicolumn{6}{|c|}{ Month after planting } & \multirow{3}{*}{ SEM } \\
\hline & & \multirow{2}{*}{$\begin{array}{l}\text { 1-Harvest } \\
\text { Month } 9\end{array}$} & \multicolumn{2}{|c|}{ 2-Harvests } & \multicolumn{3}{|c|}{ 3-Harvests } & \\
\hline & & & Month 6 & Month 9 & Month 3 & Month 6 & Month 9 & \\
\hline \multicolumn{9}{|c|}{ Dry matter (DM, \%) } \\
\hline & K94 & $28.2^{\mathrm{aY}}$ & $26.1^{\mathrm{bY}}$ & $22.7^{\mathrm{cY}}$ & $19.1^{\mathrm{dY}}$ & $19.8^{\mathrm{dY}}$ & $22.4^{\mathrm{cY}}$ & \\
\hline & K98-7 & $27.8^{\mathrm{aY}}$ & $26.4^{\mathrm{bY}}$ & $22.5^{\mathrm{cY}}$ & $19.4^{\mathrm{dY}}$ & $19.8^{\mathrm{dY}}$ & $22.2^{\mathrm{cY}}$ & \\
\hline & Local & $29.2^{\mathrm{aX}}$ & $27.4^{\mathrm{bX}}$ & $23.4^{\mathrm{cX}}$ & $20.3^{\mathrm{dX}}$ & $21.0^{\mathrm{dX}}$ & $23.2^{\mathrm{cX}}$ & 0.33 \\
\hline \multicolumn{9}{|c|}{ Crude rotein (\% of DM) } \\
\hline & K94 & $18.6^{\mathrm{b}}$ & $19.5^{\mathrm{ab}}$ & $19.7^{\mathrm{ab}}$ & $20.7^{\mathrm{a}}$ & $20.0^{\mathrm{ab}}$ & $19.7^{\mathrm{ab}}$ & \\
\hline & K98-7 & $18.6^{\mathrm{b}}$ & $19.4^{\mathrm{ab}}$ & $19.8^{\mathrm{ab}}$ & $20.5^{\mathrm{a}}$ & $19.9^{\mathrm{ab}}$ & $19.4^{\mathrm{ab}}$ & \\
\hline & Local & $18.5^{\mathrm{b}}$ & $19.6^{\mathrm{ab}}$ & $19.6^{\mathrm{ab}}$ & $20.8^{\mathrm{a}}$ & $20.1^{\mathrm{ab}}$ & $19.6^{\mathrm{ab}}$ & 0.43 \\
\hline \multicolumn{9}{|c|}{ Ash (\% of DM) } \\
\hline & K94 & 5.8 & 5.6 & 5.6 & 5.7 & 5.7 & 5.8 & \\
\hline & K98-7 & 5.7 & 5.5 & 5.5 & 5.5 & 5.5 & 5.5 & \\
\hline & Local & 5.8 & 5.6 & 5.6 & 5.7 & 5.7 & 5.7 & 0.11 \\
\hline \multicolumn{9}{|c|}{$\mathrm{NDF}(\%$ of DM) } \\
\hline & K94 & $39.4^{\mathrm{aY}}$ & $38.8^{\mathrm{abY}}$ & $37.9^{\mathrm{b}}$ & $36.4^{\mathrm{cY}}$ & $36.7^{\mathrm{cY}}$ & $37.9^{\mathrm{b}}$ & \\
\hline & K98-7 & $39.4^{\mathrm{aY}}$ & $38.3^{\mathrm{abY}}$ & $37.8^{\mathrm{b}}$ & $36.5^{\mathrm{cY}}$ & $36.4^{\mathrm{cY}}$ & $37.7^{\mathrm{b}}$ & \\
\hline & Local & $43.2^{\mathrm{aX}}$ & $41.0^{\mathrm{bX}}$ & $38.5^{\mathrm{c}}$ & $38.1^{\mathrm{cX}}$ & $38.4^{\mathrm{cX}}$ & $38.5^{\mathrm{c}}$ & 0.53 \\
\hline \multicolumn{9}{|c|}{$\mathrm{ADF}(\%$ of $\mathrm{DM})$} \\
\hline & K94 & $28.5^{\mathrm{aY}}$ & $27.4^{\mathrm{bY}}$ & $25.6^{\mathrm{cY}}$ & $27.0^{\mathrm{bcY}}$ & $26.2^{\mathrm{cXY}}$ & $26.0^{\mathrm{cXY}}$ & \\
\hline & K98-7 & $28.3^{\mathrm{aY}}$ & $27.1^{\mathrm{bY}}$ & $25.5^{\mathrm{cY}}$ & $26.8^{\mathrm{bY}}$ & $25.8^{\mathrm{cY}}$ & $25.7^{\mathrm{cY}}$ & \\
\hline & Local & $31.6^{\mathrm{aX}}$ & $29.5^{\mathrm{bX}}$ & $27.3^{\mathrm{dX}}$ & $28.2^{\mathrm{cX}}$ & $27.0^{\mathrm{dX}}$ & $26.8^{\mathrm{dX}}$ & 0.59 \\
\hline
\end{tabular}

${ }^{1}$ Cassava varieties: K94, K98-7 and local = very bitter, medium bitter and sweet taste, respectively.

a,b,c,d Numbers followed by the same letters were not significantly different $(\mathrm{p}<0.05)$ within a row.

${ }_{\mathrm{X}, \mathrm{Y}}$ Numbers followed by the same letters were not significantly different $(\mathrm{p}<0.05)$ within column.

Least square means and standard error of means (SEM).

older leaves was higher in all varieties (Table 4). Older leaves also had a higher content of DM, NDF and ADF. The opposite trend was found for the $\mathrm{HCN}$ and $\mathrm{CP}$ contents, which were higher in the younger leaves.

\section{DISCUSSION}

Effect of harvesting interval and variety on yield and CP Different harvesting intervals had a considerable effect on the foliage yield of DM and CP of the three cassava

Table 3. Content of total tannins and $\mathrm{HCN}$ of three varieties of cassava foliage with a three, two or one harvest system at 3, 6, and 9 months after planting

\begin{tabular}{|c|c|c|c|c|c|c|c|c|}
\hline \multirow{3}{*}{ Content } & \multirow{3}{*}{ Variety $^{1}$} & \multicolumn{6}{|c|}{ Month after planting } & \multirow{3}{*}{ SEM } \\
\hline & & \multirow{2}{*}{$\begin{array}{c}\text { 1-Harvest } \\
\text { Month } 9\end{array}$} & \multicolumn{2}{|c|}{ 2-Harvests } & \multicolumn{3}{|c|}{ 3-Harvests } & \\
\hline & & & Month 6 & Month 9 & Month 3 & Month 6 & Month 9 & \\
\hline \multicolumn{9}{|c|}{ Total tannins (\% DM) } \\
\hline & K94 & $4.36^{\mathrm{a}}$ & $3.77^{\mathrm{b}}$ & $2.42^{\mathrm{d}}$ & $2.86^{\mathrm{c}}$ & $2.50^{\mathrm{d}}$ & $2.17^{\mathrm{d}}$ & \\
\hline & K98-7 & $4.20^{\mathrm{a}}$ & $3.70^{\mathrm{b}}$ & $2.34^{\mathrm{d}}$ & $2.76^{\mathrm{c}}$ & $2.40^{\mathrm{d}}$ & $2.09^{\mathrm{d}}$ & \\
\hline & Local & $4.13^{\mathrm{a}}$ & $3.44^{\mathrm{b}}$ & $2.21^{\mathrm{d}}$ & $2.74^{\mathrm{c}}$ & $2.23^{\mathrm{d}}$ & $2.06^{\mathrm{d}}$ & 0.18 \\
\hline \multicolumn{9}{|c|}{$\mathrm{HCN}$ content $(\mathrm{mg} / \mathrm{kg} \mathrm{DM})$} \\
\hline & K94 & $1,736^{\mathrm{eX}}$ & $2,069^{\mathrm{dX}}$ & $3,097^{\mathrm{cX}}$ & $3,225^{\mathrm{bX}}$ & $3,689^{\mathrm{aX}}$ & $3,210^{\mathrm{bcX}}$ & \\
\hline & K98-7 & $1,294^{\mathrm{eY}}$ & $1,641^{\mathrm{dY}}$ & $2,655^{\mathrm{bY}}$ & $2,498^{\mathrm{cY}}$ & $3,067^{\mathrm{aY}}$ & $2,714^{\mathrm{bY}}$ & \\
\hline & Local & $1,056^{\mathrm{eZ}}$ & $1,318^{\mathrm{dZ}}$ & $2,258^{\mathrm{bZ}}$ & $1,716^{\mathrm{cZ}}$ & $2,567^{\mathrm{aZ}}$ & $2,376^{\mathrm{bZ}}$ & 42.8 \\
\hline
\end{tabular}

\footnotetext{
${ }^{1}$ Cassava varieties: K94, K98-7 and local = very bitter, medium bitter and sweet taste, respectively.

a,b,c,d,e Numbers followed by the same letters were not significantly different $(\mathrm{p}<0.05)$ within a row.

$\mathrm{X}, \mathrm{Y}, \mathrm{Z}$ Numbers followed by the same letters were not significantly different $(\mathrm{p}<0.05)$ within column.

Least square means and standard error of means (SEM).
} 
Table 4. Dry matter (DM) content, chemical composition and HCN content of three varieties of cassava foliage at different stages of maturity at root harvest, 9 months after planting

\begin{tabular}{|c|c|c|c|c|c|c|c|}
\hline & \multicolumn{2}{|c|}{ K94 ${ }^{1}$} & \multicolumn{2}{|c|}{ K98-7 ${ }^{1}$} & \multicolumn{2}{|c|}{ Local $^{1}$} & \multirow{2}{*}{ SEM } \\
\hline & Oldest & Youngest & Oldest & Youngest & Oldest & Youngest & \\
\hline \multicolumn{8}{|c|}{ Dry matter content $(\%)$} \\
\hline & $30.3^{\mathrm{b}}$ & $25.5^{\mathrm{d}}$ & $30.1^{\mathrm{b}}$ & $25.4^{\mathrm{d}}$ & $31.2^{\mathrm{a}}$ & $26.4^{\mathrm{c}}$ & 0.39 \\
\hline \multicolumn{8}{|c|}{ Content ( $\%$ of DM) } \\
\hline Crude protein & $18.3^{\mathrm{b}}$ & $20.5^{\mathrm{a}}$ & $18.0^{\mathrm{b}}$ & $20.6^{\mathrm{a}}$ & $17.8^{\mathrm{b}}$ & $20.4^{\mathrm{a}}$ & 0.36 \\
\hline Ash & 5.9 & 5.8 & 5.9 & 5.7 & 6.0 & 5.8 & 0.11 \\
\hline $\mathrm{NDF}$ & $39.8^{\mathrm{b}}$ & $33.5^{\mathrm{c}}$ & $39.7^{\mathrm{b}}$ & $33.4^{\mathrm{c}}$ & $44.0^{\mathrm{a}}$ & $35.3^{\mathrm{c}}$ & 0.87 \\
\hline $\mathrm{ADF}$ & $30.6^{\mathrm{a}}$ & $24.7^{\mathrm{b}}$ & $30.7^{\mathrm{a}}$ & $24.6^{\mathrm{b}}$ & $30.9^{\mathrm{a}}$ & $26.5^{\mathrm{b}}$ & 0.89 \\
\hline Total tannins & $4.40^{\mathrm{a}}$ & $3.90^{\mathrm{b}}$ & $4.32^{\mathrm{a}}$ & $3.90^{\mathrm{b}}$ & $4.26^{\mathrm{a}}$ & $3.86^{\mathrm{b}}$ & 0.07 \\
\hline \multicolumn{8}{|c|}{ Content (mg/kg DM) } \\
\hline $\mathrm{HCN}$ & $1,469^{\mathrm{b}}$ & $1,988^{\mathrm{a}}$ & $1,155^{\mathrm{c}}$ & $1,479^{\mathrm{b}}$ & $985^{\mathrm{d}}$ & $1,197^{\mathrm{c}}$ & 22.34 \\
\hline
\end{tabular}

${ }^{1}$ Cassava varieties: K94, K98-7 and local = very bitter, medium bitter and sweet taste, respectively.

${ }_{\text {a,b,c,d }}$ Numbers followed by the same letters were not significantly different $(\mathrm{p}<0.05)$ within a row.

Least square means and standard error of means (SEM).

varieties examined in the present study. Higher harvesting frequencies gave greater yields of total $\mathrm{DM}$ and $\mathrm{CP}$. According to Phengvilaysouk and Wanapat (2008), the total DM yield of cassava foliage for three cuts performed every 2 months from 4 months after planting was 6.5 tons/ha, while higher yields ( 7.5 tons/ha) were obtained for four 2monthly cuts starting 2 months after planting. Khang et al. (2005) also showed that when cassava foliage was harvested in 4, 3 and 2 cuts (every 45, 60 and $90 \mathrm{~d}$, respectively, starting $105 \mathrm{~d}$ after planting), DM production was $4.57,3.53$ and 2.49 tons/ha, respectively. The total DM production of cassava foliage in the present study (5.3 to 6.3 tons/ha) was in the range reported by Wanapat (2001), who found that the total DM yield of foliage can vary from 2 to 8 tons/ha, depending on cassava variety, cultivation practices and fertiliser supply.

Even though a single harvest, at 9 months after planting, produced higher yields than any other harvests in the months, it did not result in a higher total foliage yield and $\mathrm{CP}$ yield than those from multiple harvest during the growing seasons. Taiz and Zeiger (1998) claimed that the physiological development such as growth stage of the plant is also an important factor affecting the foliage production. The leaves drop following sequential senescence as they reach a certain age, which in cassava occurs from 60 to $120 \mathrm{~d}$. Through harvesting foliage every 3 months as in the three harvest treatment, it may be possible to avoid leaves reaching the stage of senescence. With more frequent cutting the plants could also produce higher quantities of foliage through stimulating faster regrowth of new shoots (Du Toit et al., 1990).

Khang et al. (2005) reported that the biomass foliage production of cassava was only about 2.2 tons/ha at $285 \mathrm{~d}$ after planting, which was much lower than the yield at 9 months in the treatment of a harvest in the present experiment (5.3 tons/ha). However, according to Ravindran (1993) and Mui (1994), foliage production can be approximately 5 tons of DM/ha at root harvesting. This variation could be due to cassava variety effect, planting date, water and fertilizer supply (Simwambana et al., 1992; Phengvilaysouk and Wanapat, 2008). Because the planting date in the present study was different from the cited studies, differences in weather conditions at different growth stage of plant development may contribute to the differences in cassava foliage yield. Sagrilo et al. (2006) found that the total production of fresh cassava leaves depended very much on climate parameters such as temperature and humidity. The average temperature and rainfall in the experimental area (Figure 1) gradually increased from April and was highest from July to September. Thus, the main season of cassava cultivation in northern Vietnam for foliage production should start in March each year in order to get the highest foliage yield during the rainy period from May to September. In the months of non growing season, foliage yield would probably be low because of unfavourable weather conditions such as low rainfall, temperature, sunshine or even fog.

The different cassava varieties produced different amounts of foliage, as also reported in many previous studies (Simwambana et al., 1992; Phengvilaysouk and Wanapat, 2008). In the present study, the K94 cassava variety always produced a higher yield of fresh biomass, or DM yield and CP was higher than the K98-7 and local varieties. This could be explained by the fact that the K94 cassava variety is slowly maturing (9 to 11 months) than other tested varieties and accumulated more biomass through production of large main stems, high proportion of twigs on the main stems and both large and thick leaf blades. In the K98-7 variety foliage production tended to decline faster over time compared with the local variety. This could 
be due to early maturity ( 7 to 10 months) and having been developed for more root yield.

\section{Effect of harvest interval, variety and leaf maturity on nutrient and $\mathrm{HCN}$ content}

According to the development stages of the cassava plant presented by Alves (2002): emergence of sprouting normally takes from 5 to $15 \mathrm{~d}$ after planting, leaf development begins at 15 to $90 \mathrm{~d}$ after planting along with the formation of root system and the establishment of canopy happens through well-developed stems and leaves at approximately 90 to $180 \mathrm{~d}$ after planting and carbohydrate translocation to roots occurs mainly during the period 180 to $300 \mathrm{~d}$ after planting followed by dormancy at $300 / 360$ days (Alves, 2002). The same author (Alves, 2002) also mentions that under tropical conditions, the maximum growth rate was achieved at 3 to 5 months while, under less favourable conditions this occurs later. In the present study, the harvests at 3 and 6 months after planting took place at the start and end of the period of canopy establishment, respectively. This assumption is confirmed by the fact that the yield at the 6 month harvest was highest in the 3-harvest system indicating that this harvest took place after a period of high growth rate of leaves and stems. The harvest at 9 months would be during the phase when a large amount of carbohydrates are partitioned to the roots. It is also the stage where the senescence of leaf increases. The lower DM yield at 9 months in the 3-harvest system is therefore not surprising.

The three varieties differ somewhat in appearance and growth. The K94 variety had bigger and softer stems compared to the local variety while the K98-7 was intermediate in this aspect. However, there were no differences between the three varieties in $\mathrm{CP}$, and tannin content and the comparatively small differences in DM, NDF and ADF content. This lack of major difference indicates that the difference in stem appearance had no major influence on the nutritive value of the foliage. Furthermore, it may also indicate that there were no large differences in stage of development between the three varieties within harvesting occasion. However, stage of development was not monitored in the experiment and therefore this hypothesis cannot be confirmed.

Large differences in $\mathrm{HCN}$ content between different cassava varieties have been reported in many studies (Hang and Preston, 2005; Ubi et al., 2008). Furthermore, Gômez and Valdivieso (1985) found that foliage $\mathrm{HCN}$ content in different varieties did not follow the same response pattern in relation to harvesting times. However, in the present experiment the varieties showed a similar response pattern with regard to the different harvesting frequencies even though there were large differences in the level of $\mathrm{HCN}$ content which seems to indicate that the effect of harvesting frequency on $\mathrm{HCN}$ content follows a general pattern. Unfavourable conditions such as drought for long periods are known to increase the HCN content (El-Sharkawy, 2006). In the present study the cassava plants were irrigated twice per month expect when it was raining and should not be a factor affecting the $\mathrm{HCN}$ content. During the last harvest, at month 9, the weather was drier and cooler compared with the previous harvest but not to such an extent that it should affect the HCN content.

The variation in foliage DM content over time could be due to differences in varieties but other factors such as plant lignification, environmental conditions, and plant age can also be important (Elias et al., 2001; Alves, 2002; Sagrilo et al., 2006). Our results showed that the DM content of the foliage increased with time in the first harvests at 3, 6 or 9 months after planting (Table 2). Old cassava leaves had a higher DM content than young leaves at 9 months in the treatment of a single harvest (Table 4). Similarly, Sagrilo et al. (2006) showed that the DM content of cassava leaf blades and stems increased with harvesting interval from 2 to 12 months after planting. They also showed that the highest water content in foliage occurred in the period of more intense leaf production, owing to the period of high rainfall that occurred simultaneously. This was confirmed in the present study, in which the DM content of cassava foliage of all varieties was lowest at the 3 and 6 month cuts in the three harvest treatment where the annual rainfall was highest during the year. Among the cassava varieties, the DM content of foliage tended to be higher in the local variety than in the other varieties.

According to Goméz and Valdivieso (1985), the CP and fibre content are the two chemical components that are mainly affected by increasing plant age, with CP decreasing and fibre content increasing as the biomass becomes older. In the present study, the protein content of the foliage was not significantly different by the varieties or harvest intervals, except for the CP content at the 3 month cut under the three harvests compared with the 9 month cut in the treatment of a harvest. This difference in CP content in plant foliage was also observed by Ravindran and Ravindran (1988) and Awoyinka et al. (1995) and could be due to different stages of maturity. In general, the $\mathrm{CP}$ content in the young leaves was significantly higher than that in the old leaves, and there was no difference in $\mathrm{CP}$ content between cassava foliage of the same age at the subsequent cuts every 3 months.

Peter and Constabel (2002) showed that the concentration of tannins varies widely between plant species. The induction of tannin formation is known to be important for defence against herbivores or as a response to mechanical damage. The variation in content of total 
tannins in cassava foliage in the present study showed the same trend as reported by Ravindran and Ravindran (1988), Hong et al. (2003), Khang et al. (2005) and Phengvilaysouk and Wanapat (2008), total tannin content in foliage increased with plant maturity. However, the content of total tannins in foliage declined slightly in the subsequent harvests (Table 3). According to Du Toit (1990), heavy pruning or browsing reduces nutrient competition in shoots and stimulates shoot re-growth. However, high carbohydrate demands generated by the rapid re-growth limit the substrate of carbon-based secondary metabolite synthesis, so the total tannin content in the new shoots is possibly lower in subsequent harvests. The range of total tannin content observed in cassava foliage in the present study ( 21 to $44 \mathrm{~g} / \mathrm{kg} \mathrm{DM}$ ) was somewhat lower than the 30 to $50 \mathrm{~g} / \mathrm{kg}$ DM reported by Ravindran (1993), but similar to the range observed by Khang et al. (2005). The content of total tannins did not differ between the cassava varieties tested here, but may differ in other cassava varieties under different experimental conditions (Goméz and Valdivieso, 1985). The content of total tannin content was lower in younger compared with older leaves at the single harvest at 9 months (Table 4) but the level was considerably higher than the tannin content in the foliage of the 3-harvest system indicating that the low tannin content in the foliage of the multiple harvest systems was not only an effect of leaf age but also an effect the more frequent cutting.

The cyanogenic glycosides linamarin and lotaustralin are known to be precursor compounds to the liberation of $\mathrm{HCN}$ on hydrolysis in cassava tissues. According to Vetter (2000), cyanogenic glycosides are mainly synthesised in the cotyledons of etiolated seedlings or in the young green leaves of mature plants and transported to other parts of the plants, such as roots. The variation in $\mathrm{HCN}$ content in cassava foliage is strongly decided by genetic factors (Caradus et al., 1990; Ravindran, 1993; Gleadow and Woodrow, 2002), and in the present study the HCN content was very different in the three different cassava varieties. At different harvesting frequencies, the $\mathrm{HCN}$ content increased by $20 \%$ of the total amount at the subsequent harvesting occasions compared with the first harvest. The $\mathrm{HCN}$ content was comparatively low in the initial harvests, irrespective of when this occurred after planting. However, when comparing Table 3 with Table 4, it can be seen that the HCN content in young leaves on the older plant with undisturbed growth until 9 months was much lower compared with the leaves harvested with 3 month intervals. This indicates that the high HCN content in the 3-harvest foliage is not only an effect of leaf age, but also an effect plant age at harvest. Furthermore, the increase in $\mathrm{HCN}$ content from the 1 st to the the 2 nd and 3rd harvests in the multiple harvest systems shows that there is also an increase in $\mathrm{HCN}$ content in the foliage when the plant is repeatedly harvested. A decrease in the cyanogenic glycosides with leaf maturation has been reported in other plant species, for example in Grevillea by Lamont (1993) and in Macadamia by Dahler et al. (1995), and forage sorghum. Nutritional factors, especially $\mathrm{N}$ supply, and sudden changes in temperature have the most pronounced effects on the actual level of cyanogenic glycosides (Caradus et al., 1990; Ravindran, 1993; Dahler et al., 1995; Gleadow and Woodrow, 2002). In practise, K98-7 and local varieties could be cultivated and used as supplemental feed for ruminants either as fresh, wilted, hay or silage, while the K94 variety should be used as hay or silage only to avoid the toxicity caused by very high concentrations of $\mathrm{HCN}$.

\section{CONCLUSIONS}

The highest harvesting frequency with 3 harvests gave the highest total DM foliage production, giving only slightly higher yields (+2 to $4 \%$ for different varieties) compared with 2 harvests but a considerably higher foliage yield (+19 to $24 \%$ ) compared with one single harvest. The greatest advantage of many harvests is that forage can be supplied several times over the season without lower total foliage production. The K94 cassava variety gave a higher foliage DM yield in the three harvesting treatments, ranging from 13 to $18 \%$, and 7 to $10 \%$ higher compared with the K98-7 and the local variety, respectively.

Comparatively small differences were found in the $\mathrm{CP}$, NDF and ADF content between varieties and harvesting intervals. The content of total tannins in cassava foliage increased with increasing leaf maturity at harvest but no differences were obtained between varieties. In contrast, the $\mathrm{HCN}$ content in cassava foliage was much lower (28 to $42 \%$ lower) in the local variety and it also declined with foliage maturity.

Viewing both yield and contents, it can be concluded that the three harvest system gives the highest yields, the highest CP content and the lowest tannin contents along with a more even foliage supply over the season. However, the three harvest system also gives the highest $\mathrm{HCN}$ contents. The local variety gave a somewhat lower yield but a much lower HCN content compared with the K94 variety. Therefore, the local sweet variety in a three harvest system may be an interesting alternative for the farmers, especially when feeding fresh foliage to animals where a high HCN content may be a problem.

\section{REFERENCES}

Alves, A. A. C. 2002. Botany and physiology. In: in Cassava: biology, production and utilization (Ed. R. J. Hillocks, J. M. 
Thresh and A. C. Belotti). Wallingford, Oxon, GBR, CABI Publishing, CAB International. Chapter 5, 67-89.

AOAC. 1990. Official methods of analysis. 15th end Association of Official Analytical Chemist., Washington, DC, USA. 1, pp. 69-90.

Arvidsson, K. and J. Sandberg. 2003. Cassava (Manihot esculenta Crantz) foliage - a crop by-product and potential protein feed for dairy cattle in Vietnam. Minor field studies no 231, SLU communications, Swedish University of Agricultural Sciences, Uppsala, Sweden.

Awoyinka, A., V. Abegunde and S. R. A. Adewusi. 1995. Nutrient content of young cassava leaves and assessment of their acceptance as a green vegetable in Nigeria. Plant Foods Hum. Nutr. 47:21-28.

Caradus, J. R., A. Mackay, J. F. L. Charlton and D. F. Chapman. 1990. Genecology of white clover (Trifolium repens L.) from wet and dry hill country pastures. N.Z. J. Agric. Res. 33:377384.

Dahler, J., C. Mcconchie and C. Turnbull. 1995. Quantification of cyanogenic glycosides in seedlings of three Macadamia (Proteaceae) species. Aust. J. Bot. 43:619-628.

Du Toit, J. T., J. P. Bryant and K. Frisby. 1990. Regrowth and palatability of Acacia shoots following pruning by African savanna browsers. Ecology 71:149-154.

Dung, N. T., I. Ledin and N. T. Mui. 2005. Intercropping cassava (Manihot esculenta Crantz) with Flemingia (Flemingia macrophylla); effect on biomass yield and soil fertility. Livest. Res. Rural Develop. 17:1-13.

El-Sharkawy, M. A. 2006. Review: International research on cassava photosynthesis, productivity, eco-physiology, and responses to environmental stresses in the tropics. Photosynthetica 44:481-512.

Elias, M., D. McKey, O. Panaud, M. Anstett and T. Robert. 2001. Traditional management of cassava morphological and genetic diversity by the Makushi Amerindians (Guyana, South America): Perspectives for on-farm conservation of crop genetic resources. Euphytica 120:143-157.

Erdmann, T. K., P. K. R. Nair and B. T. Kang. 1993. Effects of cutting frequency and cutting height on reserve carbohydrates in Gliricidia sepium (Jacq.) Walp. For. Ecol. Manage. 57:45-60.

Gleadow, R. M. and I. E. Woodrow. 2002. Mini-Review: constraints on effectiveness of cyanogenic glycosides in herbivore defense. J. Chem. Ecol. 28:1301-1313.

Gómez, G. and M. Valdivieso. 1985. Cassava foliage: chemical composition, cyanide content and effect of drying on cyanide elimination. J. Sci. Food Agric. 36:433-441.

Hang D. T. and T. R. Preston. 2005. The effects fo simple processing methods of cassava leaves on $\mathrm{HCN}$ content and intake by growing pigs. Livest. Res. Rural Dev. 17:99. http://www.lrrd.org/lrrd17/9/hang17099.htm

Hong, N. T. T., M. Wanapat, C. Wachirapakorn, P. Pakdee and P. Rowlinson. 2003. Effects of timing of initial cutting and subsequent cutting on yields and chemical compositions of cassava hay and its supplementation on lactating dairy cows. Asian-Aust. J. Anim. Sci. 16:1763-1769.

Hue, K. T., D. T. T. Van, I. Ledin, E. Spörndly and E. Wredle. 2010. Effect of feeding fresh, wilted and sun-dried foliage from cassava (Manihot esculenta Crantz) on the performance of lambs and their intake of hydrogen cyanide. Livest. Sci. 131:
155-161

Khang, D. N., H. Wiktorsson and T. R. Preston. 2005. Yield and chemical composition of cassava foliage and tuber yield as influenced by harvesting height and cutting interval. AsianAust. J. Anim. Sci. 18:1029-1035.

Lamont, B. B. 1993. Injury-induced cyanogenesis in vegetative and reproductive parts of two Grevillea species and their F1 hybrid. Ann. Bot. 71:537.

Mlingi, N. L. V., Z. A. Bainbridge, N. H. Poulter and H. Rosling. 1995. Critical stages in cyanogen removal during cassava processing in southern Tanzania. Food Chem. 53:29-33.

Mui, N. T. 1994 Economic evaluation of growing Elephant grass, Guinea grass, Sugarcane and Cassava as animal feed or as cash crops on Bavi high land. In: Sustainable Livestock Production on Local Feed Resources. Agricultural Publishing House, p. 16-19.

Oni, A. O., C. F. I. Onwuka, O. M. Arigbeda, U. Y. Anele, O. O. Oduguwa, O. S. Onifade and Z. L. Tan. 2011. Chemical composition and nutritive value of four varieties of cassava leaves grown in South-Western Nigeria. J. Anim. Physiol. Anim. Nutr. 95:583-590.

Peters, D. J. and C. P. Constabel. 2002. Molecular analysis of herbivore induced condensed tannin synthesis: cloning and expression of dihydroflavonol reductase from trembling aspen (Populus tremuloides). Plant J. 32:701-712.

Phengvichith, V., S. Ledin, P. Horne and I. Ledin. 2006. Effects of different fertilizers and harvest frequencies on foliage and tuber yield and chemical composition of foliage from two cassava (Manihot esculenta, Crantz) varieties. Tropic. Subtropic. Agroeco. 6:178-187.

Phengvilaysouk, A. and M. Wanapat. 2008. Study on the effect of harvesting frequency on cassava foliage for cassava hay production and its nutritive value. Livest. Res. Rural Develop. 20.

Ravindran, G. and V. Ravindran. 1988. Changes in the nutritional composition of cassava (Manihot esculenta Crantz) leaves during maturity. Food Chem. 27:299-309.

Ravindran, V. 1993. Cassava leaves as animal feed: potential and limitations. J. Sci. Food Agric. 61:141-150.

Reed, J. D., R. E. McDowell, P. J. Van Soest and J. Horvath. 1982. Condensed tannins: A factor limiting the use of cassava forage. J. Sci. Food Agric. 33:213-220.

Sagrilo, E., P. S. Vidigal Filho, M. G. Pequeno, M. C. G. Vidigal, C. A. Scapim, M. V. Kvitschal, R. R. Maia and F. Rimoldi. 2006. Effect of harvest period on foliage production and dry matter distribution in five cassava cultivars during the second plant cycle. Brazil. Archive. Biol. Technol. 49:1007-1018.

SAS, 2008. SAS/Stat 9.2 User's guide. SAS Institute Inc., Cary, NC, USA.

Simwambana, M. S. C., T. U. Ferguson and D. S. O. Osiru. 1992. The effects of time to first shoot removal on leaf vegetable quality in cassava (Manihot esculaenta Crants). J. Sci. Food Agric. 60:319-325.

Stochmal, A. and W. Oleszek. 1997. Changes of cyanogenic glucosides in white clover (Trifolium repens L.) during the growing season. J. Agric. Food Chem. 45:4333-4336.

Taiz, L. and E. Zeiger. 1998. Plant Physiology. Sunderland, Massachusetts: Sinauer.

van Soest, P. J., J. B. Robertson and B. A. Lewis. 1991. Methods 
for dietary fiber, neutral detergent fiber, and nonstarch polysaccharides in relation to animal nutrition. J. Dairy Sci. 74: 3583-3597.

Ubi, B. E., U. A. Ibiam, A. A. Effisue, E. M. Odu, K. I. Udeh and C. N. Egesi. 2008. Varietal differences in leaf cyanide content of cassava (Manihot esculentum Crantz). J. Agric. Biotechnol. Ecol. 1:62-69.

Vetter, J. 2000. Plant cyanogenic glycosides. Toxicon., 38:11-36.
Wanapat, M. 2001. Role of cassava hay as animal feed in the tropics. In proceeding of the international workshop on current research and development on use as cassava as animal feed. (Ed. T. R. Preston, B. Ogle and M. Wanapat), Khon Kean University, Thailand.

Wanapat, M. 2003. Manipulation of cassava cultivation and utilization to improve protein to energy biomass for livestock feeding in the tropics. Asian-Aust. J. Anim. Sci. 16:463-472. 